\title{
Contributions of Saudi Institutions in Applied Linguistics' Journals Indexed in SSCI: Perspectives from Academics and Journals' Editors
}

\author{
Mohammed Ali Mohsen \\ Department of English and Translation, Najran University, Saudi Arabia \\ E-mail: mmohsen1976@gmail.com
}

Received: 21-02-2016

Published: 01-07-2016
Accepted: 25-04-2016

doi:10.7575/aiac.ijalel.v.5n.4p.102
Advance Access Published: May 2016

URL: http://dx.doi.org/10.7575/aiac.ijalel.v.5n.4p.102

\begin{abstract}
There is a new tendency for institutions to augment their publications in journals indexed in the Social Science Citation Index (SSCI). Non-native English researchers may find it hard to get their submissions published in applied linguistics journals that are solely indexed in SSCI, which are known for their high rate of rejection. This could minimize the opportunity for researchers to get their manuscripts accepted for publication. This paper aims to collect data for academics' perceptions of Saudi institutions to see their attitudes towards submitting and publishing in these journals. The article also aims to check the perceptions of journals' editors on the submissions affiliated to Saudi universities to check the rate of rejection and the main reasons that lie behind the rejection. Thirty seven academics responded to an online survey designed to gauge their perceptions about submitting and publishing in applied linguistics journals indexed in SSCI. Academics perceive that publishing in such journals is difficult due to the high rate of rejection, long time of turnaround review, and a stringent peer review. Editors - those who responded to another survey — reported that a combination of outdated issues being investigated, poor research design and the lack of generalizability of research findings are the main reasons for rejecting submissions from Saudi academic institutions. On the bases of the study findings, limitations and tips for future studies are highlighted.
\end{abstract}

Keywords: perceptions, Web of Science, Social Science Citation Index, applied linguistics

\section{Introduction}

Publication in scholarly journals is becoming a must in getting ones' promotion and tenure (P\&T) in academia. Institutions assess academics' accomplishments not only on a number of publications an author has but also in how such contributions are published in top-tier journals, operationalized by databases' impact factors such as that of Web of Science. Indeed, there are other metrics used by institutions to gauge the quality of authors' publications such as numbers of downloads, citations, hits, and h-index (Rojas-Sola and Aguilera-Garcia, 2015; Long, Huang, \& Ho, 2014). That is because institutions aspire to obtain a high rank among universities which is mainly based on number of published documents that carry the institutions' affiliations besides the total of cited article related to these institutions (see Times Higher Education, 2016). In this regard, some institutions adopt stringent requirements to induce academics to publish in highly ranking journals indexed by international databases, the most reliable among these being Thompson Reuters' Web of Science and its Social Science Citation Index (SSCI) or Arts and Humanities Index (A\&HCI). These requirements make authors fall under the pressure of "publish or perish" syndrome, resulting in P\&T, renewal of contracts, increment of salaries, granting subsidies and bonus. In contrast, they might lose jobs, get delayed in promotion or lost funds. (Lee, 2014). Saudi institutions, like any other institutions, privilege academics whose papers appeared in SCCI by increasing their salaries, funding their projects and granting them bonus. Despite these privileges, the output of Saudi academics' contributions is still scarce. Therefore, this paper aims to shed light on the contributions of Saudi institutions in applied linguistics' journals indexed in SSCI and check the academics' perspectives towards submitting and publishing in such journals. It also aims to investigate the rate of submissions from Saudi institutions and the main reasons for rejecting such submissions from the perspectives of the journals' editors.

Most academic institutions adopt the Web of Science's (WOF) assessment to measure the journals' status as quantified by an impact factor (IF). An impact factor is defined as "a measure of the frequency with which the "average article" in a journal has been cited in a particular year or period.....the impact factor of a journal is calculated by dividing the number of current year citations to the source items published in that journal during the previous two years" (Web of Science n.d). On the basis of IF, the journal citation report (JCR) is issued every year for both SSCI and SCI indexes, indicating how valuable a particular journal is as based on number of citations of that journal's articles in other journals that are solely indexed in WoF. In the field of linguistics, there are over hundreds of journals indexed in SSCI and this number is expanding every year. These journals are categorized as quintiles; Q1,Q2, Q3, and Q4. Q1 refers to the top $25 \%$ of the journals as ranked by highest IF, Q2 refers to the highest IF of the second quarter of journals and so on. 
According to JCR issued in 2014, there are 179 journals in the category of linguistics; covering several sub-fields in language and linguistics such as applied linguistics, translation, phonetics, pragmatics and other sub-fields. The criteria used by WoS to index a journal are timeliness, peer review, international editorial convention, international editorial convention, and citation analysis. Thus, journals indexed in SSCI are known of having high prestige and stringent peer review. Therefore, publishing in such journals seems hard for authors especially for researchers in countries where English is learned or taught as a foreign language.

SSCI journals are receiving tremendous submissions from different parts of the world, even more than they publish because authors are keen on to get a chance of getting their papers published in these journals. Authors believe that publishing in such journals adds some prestige to their papers and to themselves as well because their articles might be highly cited, viewed or downloaded. This leads to huge submissions received by the journals which obviously result in increasing the rate of rejection for the submissions (Web of Science n.d). Some journals desk rejected submissions without review because they feel that either the submission does not fit the journal's stature or the manuscript is poorly written, designed, not well-referenced or the findings were not globally generalized. The rate of rejection varies from journal to another. For example, Language Learning \& Technology Journal had received over 150 manuscripts during the year 2007, and $90 \%$ of them had been desk-rejected based on in-house review (Byrnes, 2010). System Journal received 610 submission during the year 2015, and around 70\% of these submissions had been desk rejected (Astruc, Gao, Mercer, \& Stickle, 2016). According to Egbert (2007) some top-tier journals have an approximate acceptance rate; 15-20 \% for Modern Language Journal, $8.5 \%$ for TESOL Quarterly, $20 \%$ for System Journal, and 10-20 \% for Studies in Second Language Acquisition Journal. This lessens the opportunities to scholars particularly those who are nonnative speakers of English to publish in high ranking journals. As a result, they search for a low ranking journals in other indices or submit their manuscripts to local journals.

In the context of Saudi Arabia, there are hundreds of researchers in applied linguistics field working over 30 academic institutions, and they are presupposed to publish their work in peer-reviewed journals to get P\&T. The policy of P\&T is mainly based on number of publications either collaboratively or individually. No restriction is made to publish work in SSCI to obtain P\&T. Yet, a great fund would be granted to authors who publish their papers in journals indexed in SSCI (an amount of $\$ 3800$ ). Not only that, a bylaw issued by the Ministry of higher education in 2010, detailing that a bonus of $30 \%$ would be granted to authors who published work in the top $10 \%$ of WoS journals in all fields of research. Despite that, few researchers from Saudi Institutions published articles in the category of linguistics field - as it is categorized SSCI —in the last 5 years (2010-2014). A quick search for Saudi contributions in the SSCI in the period 2010-2014 indicates that only 35 documents were published in language and linguistics journals during the last 5 years, which is a scarce. Of these documents; 27 articles and 8 documents contain book review, review, editorial materials, and correction (see https://apps-webofknowledge.com.sdl.idm.oclc.org/Search.do?product=WOS\&SID= N288Ko6nsoDJMziuArQ\&search_mode=GeneralSearch\&prID=3c72cad7-34d8-40ee-8226-aa9517c8d712).

It is therefore of a paramount importance to check the academics' perceptions towards submissions to such journals. It is also important to check the perceptions of the journals' editors towards the submissions and what the main reasons for rejections are. Hence, this article aims to address the following research questions:

1.How do Saudi institutions' researchers perceive submitting manuscripts to applied linguistics' journals indexed in SSCI?

2.Do academics from Saudi institutions attempt submitting their manuscript to the applied linguistics journals indexed in SSCI? If yes, how many rejections are there and what are the main reasons for rejections as perceived by the journals' editors?

\section{Methodology}

An online survey has been designed to elucidate the academics' perceptions towards submitting and publishing in SSCI journals. It starts introducing the issue of research and the objectives of the survey. To adhere to the ethics of research, the survey asks the participants first if they agree on terms and conditions of the survey (e.g, confidentiality of the respondents, their voluntary participation) by ticking yes on the mandatory statement. If a respondent ticks "yes", he or she will be able to complete the survey. The survey asks about the demographic information of the respondents; gender, academic position, areas of specialism in applied linguistics. It then contains 25 items pertaining to researchers, institutions, and submitting and publishing in the journals. The survey has been constructed by using 4-5 multiple choice items and one open answer question if the participant wants to add extra information on the item. The last item is open ended question which is given to respondents to comment on the whole items of the survey. The survey has been designed using Google drive as one response per person. The first draft of the survey had been given to 3 researchers to check the suitability of the items and to validate the items. Some items had been reconstructed as per the panel's suggestions. Finally, the final draft had been constructed using Google Drives documents and then the link had been circulated to respondents through different channels such as personal emails, institutions' emails, Facebook accounts, WhatsApp, and Research gate's accounts. The link had been sent to 161 academics in almost 20 universities whose contacts appeared on their institutions' websites. 37 respondents (23\%) agreed to complete the survey; one answer had been received by mistake to an academic in Computer Science, and then his/her response was not calculated. The demographic information about respondents are summarized in Table 1.

To answer the second research question, another online survey had been constructed to know about the submissions sent to the journals and how were decisioned by the journals' editors. The survey contained of 7 items, asking about the 
total submissions received by a journal, total desk rejected submissions, total submissions rejected after review, total submissions received major revision, total submission accepted for publications, and the main reasons for rejection. These questions are crucial to see if there are attempts of academics to publish in these journals and to recognize the major faults of these submissions which led to rejection. The survey has been sent to 9 journals; TESOL Quarterly, Modern Language Journal, Studies in Second Language Acquisition, Language Learning, Foreign Language Annals, ELT Journal, Language Learning \& Technology, Annual Review of Applied Linguistics, and Computer assisted Language Learning. These journals are classified as the top-tier journals in applied linguistics field (Smith \& Lafford, 2009)

\section{Results and Analysis}

\subsection{Researchers}

The respondents showed awareness to different concepts of research publishing. For example, $62 \%$ of participants affirmed that they followed the Journal citation Report (JCR) that issued by Thompson Reuters every year. $64 \%$ of the respondents knew the ranking of the applied linguistics journals according to their impact factors. 83.7\% also revealed that they were aware of the scope of the journals in their area of research. $29 \%$ recognized journals from other disciplines that can publish articles in applied linguistics field. 89.2\% showed interest in abstracting and indexing of the venue of publication. Only one academic worked in the editorial board in one journal. For the productivity of the academics (see Table 2). 21\% published at least one article, $16 \%$ published at least two articles, one academic published 3 articles (2.6\%), $10 \%$ published more than 4 articles, while $51 \%$ never published yet.

Table 1. Demographic information about the respondents

\begin{tabular}{|c|c|c|c|c|c|c|c|c|c|c|c|c|}
\hline & \multicolumn{2}{|l|}{ Gender } & \multicolumn{4}{|c|}{ Academic position } & \multicolumn{6}{|c|}{ Areas of Research } \\
\hline & Male & Female & Lecturer & $\begin{array}{l}\text { Assistant } \\
\text { prof }\end{array}$ & $\begin{array}{l}\text { Associate } \\
\text { prof }\end{array}$ & Prof & $\begin{array}{l}\text { applied } \\
\text { linguistics }\end{array}$ & TESOL & SLA & ELT & CALL & Others \\
\hline Respondents & $\begin{array}{l}32 \\
(86.4 \%)\end{array}$ & $\begin{array}{l}5 \\
(13.5 \%)\end{array}$ & $\begin{array}{l}12 \\
(32.4 \%)\end{array}$ & $\begin{array}{l}17 \\
(46 \%)\end{array}$ & $\begin{array}{l}6 \\
(16.2 \%)\end{array}$ & $\begin{array}{l}2 \\
(5.4 \%)\end{array}$ & $\begin{array}{c}19 \\
(51.3 \%)\end{array}$ & $\begin{array}{c}5 \\
(13.5 \%)\end{array}$ & $\begin{array}{r}2 \\
(5.4 \%)\end{array}$ & $\begin{array}{c}2 \\
(5.4 \%)\end{array}$ & $\begin{array}{c}4 \\
(10.8 \%)\end{array}$ & $\begin{array}{c}5 \\
(13.5 \%)\end{array}$ \\
\hline
\end{tabular}

Table 2. Items pertaining to Researchers

\begin{tabular}{|c|c|c|c|c|c|}
\hline Ser. & Item & Yes & Percentage & No & percentage \\
\hline 1. & $\begin{array}{l}\text { I am aware of the journal citation reports published by } \\
\text { Thomson Reuters every year }\end{array}$ & 23 & $62 \%$ & 14 & $38 \%$ \\
\hline 2. & I know the rank of journals in my discipline & 24 & $64.2 \%$ & 13 & $35.8 \%$ \\
\hline 3. & $\begin{array}{l}\text { I am aware of the scope and guidelines for authors to } \\
\text { journals in my discipline }\end{array}$ & 31 & $83.7 \%$ & 6 & $16.3 \%$ \\
\hline 4. & $\begin{array}{l}\text { I am aware of journals from different disciplines that can } \\
\text { publish articles in some areas of applied linguistics }\end{array}$ & 29 & $78.3 \%$ & 8 & $21.7 \%$ \\
\hline 5. & I am aware of the unrefereed journals in my area & 22 & $59.4 \%$ & 15 & $40.5 \%$ \\
\hline 6. & Indexing and abstracting for journals are important to me & 33 & $89.2 \%$ & 4 & $10.8 \%$ \\
\hline 7. & Do you work in the editorial board of any SSCI journals? & 1 & $2.7 \%$ & 36 & 97.3 \\
\hline
\end{tabular}

\subsection{Institutions}

The answers from respondents concerning the institutions' policy in regards to publishing in SSCI vary from one institution to another. Some respondents (54\%) revealed that their institutions urged them to publish in SSCI journals while $46 \%$ of the respondents reported the opposite. $76 \%$ of the respondents' answers revealed that it was not compulsory to get an academic promotion if they publish in SSCI journals. About half of participants (51\%) showed that their institutions funded them if they would publish in SSCI journals. Respondent showed negative attitudes towards their institutions in terms of funding and granting authors for publishing in SSCI (see Table 3).

Table 3. Attitudes towards institutions

\begin{tabular}{|c|c|c|c|c|c|}
\hline Ser. & Item & Yes & percentage & No & percentage \\
\hline 1. & $\begin{array}{l}\text { My institution urges me to publish in SSCI } \\
\text { journals }\end{array}$ & 20 & $54 \%$ & 17 & $46 \%$ \\
\hline 2. & $\begin{array}{l}\text { My institution stipulates that I must publish in } \\
\text { SSCI to get an academic promotion }\end{array}$ & 9 & $24.3 \%$ & 28 & $75.7 \%$ \\
\hline 3. & $\begin{array}{l}\text { My institution stipulates that I should publish my } \\
\text { articles in SSCI journals in order to get funds }\end{array}$ & 19 & $51 \%$ & 18 & $49 \%$ \\
\hline 4. & $\begin{array}{l}\text { My institution grants an extra allowance for those } \\
\text { who published in SSCI }\end{array}$ & 3 & $8.1 \%$ & 34 & $91.8 \%$ \\
\hline
\end{tabular}


The section is very important to recognize the obstacles the academics encountered when submitting their manuscripts to SSCI journals of applied linguistics. In answering the $15^{\text {th }}$ item of the survey, (32.4\%) of the respondents complained the long turnaround of review of these journals, possibly because of the huge submissions received by authors worldwide and the voluntary work of the reviewers' panel of the journals. $27 \%$ of the respondents reported that many researchers may not prefer to submit their manuscripts due to the high rate of rejections of these journals, while $8 \%$ of the respondents ascribed that to the rigorous peer review. One respondent said that it was because of the high writing style while $27 \%$ chose "all the above" option (see Table 4). For the 16 th item, 37\% said that the less interest shown by some researchers to send their submissions to SSCI journals were due to a combination of (1) non-requirement for academic promotion, (2) not a condition for a contract renewal, and (3) it has nothing to do with salary increment (for details see Table 5).

Concerning the attempt of submission to SSCI journals of applied linguistics ( $17^{\text {th }}$ item), $24 \%$ of the respondents got desk rejection, $54 \%$ never tried yet, $8 \%$ of them got major revision and then rejected, $10 \%$ received major revision and then got accepted, while one respondent commented that "my research topic lies outside the scope of the journal". The respondents answered the item 18 by saying that the main reason for attempting to publish in these journals was their wish to be cited more (35\%). $27 \%$ of the respondents had great desire to do so, while the options "I have good research capabilities" and "My investigated issue is of international scope" got $19 \%$ for each. For the best type of SSCI journals the academics want to publish in, $60 \%$ of the participants preferred SSCI journals in their major regardless the high impact factor a journal has, while $21 \%$ preferred to publish in a high impact factor regardless the occurrence of the journal to the researchers' area of interest.

For the academics' perceptions towards the poor contribution of Saudi institutions in SSCI journals of applied linguistics, 29\% reasoned that to academic overload of researchers. $22 \%$ justified that the institutions did not reward researchers, $16 \%$ said that it was due to the high rate of rejection, $19 \%$ reported this to non-requirement of P\&T.

$11 . \%$ suffered from the delay in getting feedback from these journals. One respondent added one reason "poor quality of submission". In regards to item $21,24 \%$ of the respondents said that the submission focused on local issues lied behind non-suitability with SSCI journals' standard. $22 \%$ responded that the submissions did not have sound methodology, $22 \%$ said that it was because of poor academic writing, $19 \%$ ticked the option pertaining to the lack of novelty of the submissions. One respondent said "Focus on indigenous problem that appear not important to the outsider".

Regarding the academics' perceptions towards the status of the publisher (item 22 ), $76 \%$ perceived that the name of publisher is important, $10.0 \%$ were undecided while others showed less or no interest for the status of the publisher. For the issue of citation (item 23), $50 \%$ never published, $20 \%$ more than three times, and $30 \%$ fewer than 3 times. Concerning their assessment to the top-tier journal, $38 \%$ of the respondents based it on high impact factor, $24 \%$ to the editors and editorial board' status, $19 \%$ for the long history of the journal, $16 \%$ for the status of the publisher, and 3\% for the high rate of rejection a journal has.

Table 4. Analysis of item 15

\begin{tabular}{|c|c|c|c|c|c|c|c|c|c|c|c|c|c|c|c|c|}
\hline \multirow[t]{2}{*}{ Item 15} & \multicolumn{2}{|c|}{ peer review } & \multicolumn{4}{|c|}{ rejection } & \multicolumn{2}{|c|}{$\begin{array}{l}\text { process of } \\
\text { review }\end{array}$} & \multicolumn{4}{|c|}{$\begin{array}{l}\text { standard of } \\
\text { writing style }\end{array}$} & \multicolumn{2}{|c|}{ above } & \multicolumn{2}{|c|}{ otner } \\
\hline & $\mathrm{N}$ & $\%$ & $\mathrm{~N}$ & & $\%$ & & $\mathrm{~N}$ & $\%$ & $\mathrm{~N}$ & & $\%$ & & $\mathrm{~N}$ & $\%$ & $\mathrm{~N}$ & $\%$ \\
\hline $\begin{array}{l}\text { Many researchers may not prefer to send their submissions to SSCI journals } \\
\text { because they believe that these journals have }\end{array}$ & 3 & 8.1 & & 10 & & 27 & 12 & 32.4 & & 1 & & 2.7 & 10 & 27 & 1 & 2.7 \\
\hline
\end{tabular}


Table 5. Analysis of item 16

\begin{tabular}{|c|c|c|c|c|c|c|c|c|c|c|}
\hline \multirow[t]{2}{*}{ Item 16} & \multicolumn{2}{|c|}{$\begin{array}{l}\text { a. it is not a requirement } \\
\text { for academic promotion }\end{array}$} & \multicolumn{2}{|c|}{$\begin{array}{l}\text { b. it is not a } \\
\text { condition for a } \\
\text { contract renewal }\end{array}$} & \multicolumn{2}{|c|}{$\begin{array}{l}\text { c. it has nothing to } \\
\text { do with salary } \\
\text { increment }\end{array}$} & \multicolumn{2}{|c|}{$\begin{array}{l}\text { d. all the } \\
\text { above }\end{array}$} & \multicolumn{2}{|c|}{ Other } \\
\hline & $\mathrm{N}$ & $\%$ & $\mathrm{~N}$ & $\%$ & $\mathrm{~N}$ & $\%$ & $\mathrm{~N}$ & $\%$ & $\mathrm{~N}$ & $\%$ \\
\hline $\begin{array}{l}\text { Some researchers show less interest in submitting their manuscripts to SSCI } \\
\text { journals because }\end{array}$ & 5 & 13.5 & 2 & 5.4 & 8 & 21.6 & 9 & 24.3 & 13 & 35 \\
\hline
\end{tabular}

$$
\text { Table 6. Analysis of item } 17
$$

\begin{tabular}{|c|c|c|c|c|c|c|c|c|c|}
\hline \multirow[t]{2}{*}{ Item 17} & a. desk rejected & $\begin{array}{l}\text { b. major revision and } \\
\text { then rejected }\end{array}$ & $\begin{array}{l}\text { c. major revision } \\
\text { and then accepted }\end{array}$ & \multicolumn{2}{|c|}{$\begin{array}{l}\text { d. minor revision } \\
\text { and then accepted }\end{array}$} & \multicolumn{2}{|c|}{$\begin{array}{l}\text { e. never tried } \\
\text { yet }\end{array}$} & \multicolumn{2}{|c|}{ Other } \\
\hline & $\%$ & $\mathrm{~N} \quad \%$ & $\mathrm{~N} \quad \%$ & $\mathrm{~N}$ & $\%$ & $\mathrm{~N}$ & $\%$ & $\mathrm{~N}$ & $\%$ \\
\hline Some researchers show less interest in submitting their manuscripts to & 24 & 3 & 13 & 0 & 0 & 20 & 54 & 1 & 2.6 \\
\hline
\end{tabular}

SSCI journals because

Table 7. Analysis of item 18

\begin{tabular}{|c|c|c|c|c|c|}
\hline Item 18 & a. I want to be cited more & $\begin{array}{l}\text { b. I have a great desire } \\
\text { to do so }\end{array}$ & $\begin{array}{l}\text { c. I have good } \\
\text { research } \\
\text { capabilities }\end{array}$ & $\begin{array}{l}\text { d. I want to } \\
\text { please the } \\
\text { journal's } \\
\text { readership }\end{array}$ & $\begin{array}{l}\text { e. My investigated } \text { Other } \\
\text { issue is of } \\
\text { international } \\
\text { scope }\end{array}$ \\
\hline
\end{tabular}

\begin{tabular}{|c|c|c|c|c|c|c|c|c|c|c|c|c|}
\hline & $\mathrm{N}$ & $\%$ & $\mathrm{~N}$ & $\%$ & $\mathrm{~N}$ & $\%$ & $\mathrm{~N}$ & $\%$ & $\mathrm{~N}$ & $\%$ & $\mathrm{~N}$ & $\%$ \\
\hline I prefer to publish my articles in SSCI journals because & 13 & $35 \%$ & 10 & $27 \%$ & 7 & $19 \%$ & 0 & 0 & 7 & $19 \%$ & 0 & 0 \\
\hline
\end{tabular}

Table 8. Analysis of item 19

\begin{tabular}{|c|c|c|c|c|c|c|c|c|c|c|}
\hline \multirow[t]{2}{*}{ Item 19} & \multicolumn{2}{|c|}{$\begin{array}{l}\text { a. high impact } \\
\text { factor journals }\end{array}$} & \multicolumn{2}{|c|}{$\begin{array}{l}\text { b. specialized in my } \\
\text { research area that is } \\
\text { indexed in SSCI }\end{array}$} & \multicolumn{2}{|c|}{$\begin{array}{l}\text { c. Indexed in } \\
\text { SSCI but not } \\
\text { specialized in my } \\
\text { area }\end{array}$} & \multicolumn{2}{|c|}{$\begin{array}{l}\text { d. not necessary to } \\
\text { be indexed in SSCI }\end{array}$} & \multicolumn{2}{|l|}{ Other } \\
\hline & $\mathrm{N}$ & $\%$ & $\mathrm{~N}$ & $\%$ & $\mathrm{~N}$ & $\%$ & $\mathrm{~N}$ & $\%$ & $\mathrm{~N}$ & $\%$ \\
\hline What type of SSCI journals do you want your paper to appear in? & 8 & 21.6 & 22 & 60 & 2 & 5.3 & 2 & 5.3 & 3 & 8 \\
\hline
\end{tabular}


Table 9. Analysis of item 20

\begin{tabular}{|c|c|c|c|c|c|c|c|}
\hline \multirow[t]{2}{*}{ Item 20} & $\begin{array}{l}\text { a. researchers are busy with } \\
\text { academic commitments }\end{array}$ & $\begin{array}{l}\text { b. institutions do not } \\
\text { reward researchers }\end{array}$ & $\begin{array}{l}\text { c. High rate of } \\
\text { rejection made by } \\
\text { these journals }\end{array}$ & $\begin{array}{l}\text { d. It is not a } \\
\text { requirement of } \\
\text { promotion and } \\
\text { tenure }\end{array}$ & $\begin{array}{l}\text { e. delay to get } \\
\text { feedback }\end{array}$ & \multicolumn{2}{|l|}{ Other } \\
\hline & $\%$ & $\%$ & $\%$ & $\%$ & $\%$ & $\mathrm{~N}$ & $\%$ \\
\hline $\begin{array}{l}\text { The reasons for poor contributions of Saudi } \\
\text { institutions in SSCI journals of applied linguistics are } \\
\text { possibly due to }\end{array}$ & 29.7 & 21.6 & 15.8 & 18.9 & 10.8 & 2.6 & \\
\hline \multicolumn{8}{|l|}{ Table 10. Analysis of item 21} \\
\hline \multirow[t]{2}{*}{$\mathrm{m} 21$} & $\begin{array}{l}\text { a. Articles focus on local } \\
\text { issues }\end{array}$ & $\begin{array}{l}\text { b. Articles do not have } \\
\text { sound research } \\
\text { methodology }\end{array}$ & $\begin{array}{l}\text { c. data assessment } \\
\text { are not sound }\end{array}$ & $\begin{array}{l}\text { d. poor academic } \\
\text { writing }\end{array}$ & $\begin{array}{l}\text { e. issues } \\
\text { investigated in } \\
\text { their publications } \\
\text { are not novel }\end{array}$ & Other & \\
\hline & $\%$ & $\%$ & $\%$ & $\%$ & $\%$ & $\mathrm{~N}$ & $\%$ \\
\hline $\begin{array}{l}\text { hink contributions of Saudi institutions do not suit } \\
\text { CI journals' standard because }\end{array}$ & $24.3 \%$ & 21.6 & 2.7 & 21.6 & 18.9 & 4 & 10.8 \\
\hline
\end{tabular}

Table 11. Analysis of item 22

\begin{tabular}{|c|c|c|c|c|c|c|c|c|c|c|}
\hline \multirow[t]{2}{*}{ Item 22} & \multicolumn{2}{|c|}{ a. important } & \multicolumn{2}{|c|}{ b. not important } & \multicolumn{2}{|c|}{ c. less important } & \multicolumn{2}{|c|}{ d. undecided } & \multicolumn{2}{|l|}{ Other } \\
\hline & $\mathrm{N}$ & $\%$ & $\mathrm{~N}$ & $\%$ & $\mathrm{~N}$ & $\%$ & $\mathrm{~N}$ & $\%$ & $\mathrm{~N}$ & $\%$ \\
\hline I consider the status of a journal's publisher is & 28 & 75.76 & 3 & 8.1 & 3 & 8.1 & 4 & 10.8 & 0 & 0 \\
\hline
\end{tabular}

Table 12. Analysis of item 23

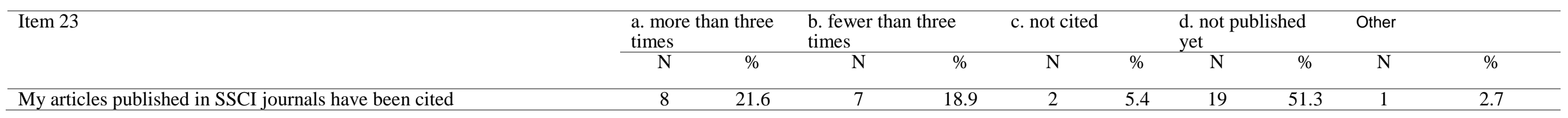

\begin{tabular}{|c|c|c|c|c|c|c|c|c|c|c|}
\hline \multirow[t]{2}{*}{ Item 24} & a. The name of the publisher & $\begin{array}{l}\text { b. long history of the } \\
\text { journal }\end{array}$ & \multicolumn{2}{|c|}{$\begin{array}{l}\text { c. high impact } \\
\text { factor }\end{array}$} & \multicolumn{2}{|c|}{$\begin{array}{l}\text { d. the editor and } \\
\text { the editorial } \\
\text { board's status }\end{array}$} & \multicolumn{2}{|c|}{$\begin{array}{l}\text { e. high rate of } \\
\text { rejection a journal } \\
\text { has }\end{array}$} & \multicolumn{2}{|c|}{ Other } \\
\hline & $\%$ & $\%$ & $\mathrm{~N}$ & $\%$ & $\mathrm{~N}$ & $\%$ & $\mathrm{~N}$ & $\%$ & $\mathrm{~N}$ & $\%$ \\
\hline $\begin{array}{l}\text { How do you judge the top tier journal that is indexed in } \\
\text { SSCI }\end{array}$ & 16.2 & 18.9 & 14 & 37.8 & 9 & 24.3 & 1 & 2.7 & 0 & 0 \\
\hline
\end{tabular}




\subsection{Answer to $R Q 2$}

Out of nine emails sent to the journals' editors of applied linguistics' field; 4 editors replied regrettably that the databases that are using did not sort submissions by country of origin. One editor replied that "unfortunately, we are unable to conduct a detailed analysis of submissions we have received in the past from Saudi Arabia. However, we are happy to share with you that most rejections are due to some combination of inadequate/outdated literature reviews, poor study design, and/or lack of generalizability of the results". One journal's editor was able to retrieve the required data and completed the survey. The journal editor replied that the journal had received 41 submissions during 9 years; 40 submissions had been desk rejected and one submission had been rejected after review. As per his/her opinion, the main reason for rejecting these submissions was that the issues being investigated were not novel.

\section{Discussion}

This study sought to understand how academics in applied linguistics category of Saudi institutions perceive submitting and publishing in journals indexed in SSCI. As it shown from the results of the survey, the academics showed a high interest in indexing and abstracting the venues of publication. They also exhibited a moderate interest in tracking the journal citation report issued by Thompson Reuters every year. Further, they showed awareness in understanding the ranking of journals in different disciplines of applied linguistics field. Concerning encouragement of institutions, the respondents showed negative attitudes towards granting bonus or extra allowance for their publications, if any, in SSCI journals. While some institutions stipulate that to get P \& T, an academic must get his/her papers published in SSCI journals, the majority of them did not compel academics to publish in SSCI journals to get P\&T. Perhaps, the poor outcomes of Saudi institutions' publications in SSCI journals - as it shown by the Web of Science- could be due to the fact that academics can get a P \&T by publishing in journals indexed in less demanding databases where they can get their articles published easily and rapidly.

Academics' perceptions varied towards submitting to SSCI journals; most of the responses indicated that the high rate of rejection and long process of review of such journals might deter them from attempting to send their submissions to the journals. As a result. The majority of the respondents never tried submitting to such journals. They revealed that the academic commitments might lie behind the poor contributions of Saudi institutions in SSCI journals of applied linguistics field. The high rate of rejection for Saudi submissions to such journals were due to-as journals' editors perceive - focusing on local issues and entailing outdated literature review.

\section{Conclusion and Limitation}

Academic of Saudi institutions aspired to publish their manuscripts in applied linguistics journals indexed in SSCI. Yet, they perceived that the high rate of rejection received by these journals, long process of review, and overload of academic commitments may lie behind the poor contributions of the Saudi institutions. In addition, majority of institutions do not compel academics to publish in such journals to get a P \& T. As a result, they tended to find less demanding journals that can publish their submissions easily. Some institutions showed less encouragement to academics to publish in such journals. Some academics suffer from academic teaching overload, no incitement from their institutions, and nor funds in return to publishing in SSCI journals. The journals' editors felt that poor research design, outdated literature review and the issues being investigated deemed as a part of the major reasons for desk rejection or rejection after review. Additionally, publishing in SSCI journals was not a requirement to get an academic promotion in academic institutions. Therefore, academics tended to publish their manuscripts in local journals or in less demanding databases to speed up the process of publishing and to get a high chance of accepting their manuscripts.

The study findings are limited to the study participants. Though, they are from different institutions and from different academic positions, the sample size is not large and the number of female academics was not enough. A big size of participants from male and female academics would be more valid for generalizing the study findings. The number of publications for Saudi institutions may be a little distracting as some journals got indexed recently and there may be other publications in these journals before they were indexed. Other publications could appear in top-tier journals like CALICO Journal which is not indexed in SSCI and contained several articles from Saudi institutions. Therefore, a bibliometric analysis study for Saudi publications in the category of linguistics in general and applied linguistics in particular is greatly needed to gauge the productivity of authors, papers and institutions (see examples of bibliometric analyses studies; Ho, 2013; Lin, \& Ho, 2015; Wong, Tam, Wong, \& Cheung, 2013). Only a survey was used to collect data from academics and that may threaten the validity of the findings as there might be some respondents that could not understand the items fully or respond it in a hurry without given much consideration to the survey, future studies are thus advised to administer interviews with academics to get a more valid results about their perceptions of publishing in SSCI journals. It is worth-mentioning that the researcher does not receive the institutions' views about their policy for a P \& T nor does he fully depict how they encourage researchers who publish in such journals. Hence, future studies are encouraged to consider the institutions' views in this regard.

\section{References}

Astruc, L., Gao, X., Mercer, S., \& Stickle, U., (2016). Editorial December 2015. System, 56, pp iv-vi.

Byrnes, H. (2010). The changing scene for publishing in applied linguistics journals: views from editors. The Modern language Journal, 94(4), 636-664.

Egbert, J. (2007). Quality analysis of journals in TESOL and applied linguistics. TESOL Quarterly, 41(1) 57-71.

Ho, Y.S. (2013), The top-cited research works in the Science Citation Index Expanded. Scientometrics,94(3), 1297-1312. 
Lee, L. (2014). Publish or perish: The myth and reality of academic publishing. Language Teaching, 47, 250- 261 doi: $10.1017 / \mathrm{S} 0261444811000504$

Long, X., Huang, J.Z. \& Ho, Y.S. (2014), A historical review of classic articles in surgery field. American Journal of Surgery, 208(5), 841-849.

Rojas-Sola, J.I. and Aguilera-Garcia, A.I. (2015), Global bibliometric analysis of the 'mining \& mineral processing' subject category from the Web of Science (1997-2012). Mineral Processing and Extractive Metallurgy Review, 36(6), 349-369.

Smith, B., \& Lafford, B. A. (2009). The Evaluation of scholarly activity in computer-assisted language learning. Modern Language Journal, 93(1), 868-883.

Times Higher Education (2016). World University Rankings 2015-2016. Retrieved from https://www.timeshighereducation.com/world-university-rankings/2016/world-

ranking\#!/page/0/length/25/sort_by/rank_label/sort_order/asc/cols/rank_only

Web of Science (2016). WEB OF SCIENCE CATEGORIES: (LANGUAGE LINGUISTICS OR LINGUISTICS ) Timespan: 2010-2014. Indexes: SSCI. Retrieved from https://apps-webofknowledgecom.sdl.idm.oclc.org/Search.do?product=WOS\&SID=N288Ko6nsoDJMziuArQ\&search_mode=GeneralSearch\&prID= 3c72cad7-34d8-40ee-8226-aa9517c8d712

Web of Science (n.d). The Thompson Reuters Impact Factor. Retrieved from http://wokinfo.com/essays/impact-factor/ Wong, E., Tam, W., Wong, F., \& Cheung, A. (2013), Citation classics in nursing journals: The top 50 most frequently cited articles from 1956 to 2011. Nursing Research, 62(5), 344-351.

\section{Note:}

i - This website is valid only for institutions that have full access to the Web of Science. 